\title{
Artifacts in the Raymond Powell Collection from East Texas
}

\author{
Jeffery S. Girard
}

Northwestern State University of Louisiana

Timothy K. Perttula

Heritage Research Center, Stephen F. Austin State University

Follow this and additional works at: https://scholarworks.sfasu.edu/ita

Part of the American Material Culture Commons, Archaeological Anthropology Commons, Environmental Studies Commons, Other American Studies Commons, Other Arts and Humanities Commons, Other History of Art, Architecture, and Archaeology Commons, and the United States History Commons

Tell us how this article helped you.

This Article is brought to you for free and open access by the Center for Regional Heritage Research at SFA ScholarWorks. It has been accepted for inclusion in Index of Texas Archaeology: Open Access Gray Literature from the Lone Star State by an authorized editor of SFA ScholarWorks. For more information, please contact cdsscholarworks@sfasu.edu. 


\section{Artifacts in the Raymond Powell Collection from East Texas}

Creative Commons License

(c) (i) (8)

This work is licensed under a Creative Commons Attribution-NonCommercial 4.0 International License 


\title{
Artifacts in the Raymond Powell Collection from East Texas
}

\author{
Jeffrey S. Girard and Timothy K. Perttula
}

In March 2010, Raymond Powell of Mansfield, Louisiana, allowed the examination and photographic documentation of several artifacts in his possession. The specimens wcre given to him approximately 60 years ago by a friend who reportedly excavated them from a burial located in either Cass County or Titus County in East Texas. The collection consists of six ceramic vessels and three stone artifacts (Figure 1). The vessels appear to relate to both the Late Caddo Titus phase (ca. A.D. 1430-1680) (Perttula 1995 , 2004; Thurmond 1990) as well as to contemporaneous sites in Bowie and Cass counties on the Red River near the Great Bend area, and the lower Sulphur River, that have been associated with the Nasoni Caddo (Perttula 2005; Perttula et al. 2010).

\section{CFRAMIC VESSELS}

The first of the six vessels is a Pease Brushed-Incised (?) jar (Figure 1a). This small vessel has five rows of punctations on the rim (an unusual mode for the type), vertical incised lines serve as panel dividers, and diagonal incised lines fill the various panels. Surfaces are polished and no temper particles are visible.

There are two Taylor Engraved vessels, a jar or deep bowl (Figure 1b) and a bottle (Figure 1d). Rim decoration on the jar or deep bowl consists of bands filled with short diagonal and vertical engraved lines. The body of the vessel has a scroll pattern common for the type. Red pigment appears in some of the lines. Surfaces are polished and the vessel appears to have sparse bone temper. The Taylor Engraved bottle is decorated with curvilinear scroll elements and hatched pendant triangles. Patches of red pigment are present on surfaces and in some lines. Surfaces are polished and the bottle appears to have grog temper.

The collection also has two Simms Engraved bowls (Figure 1c, e). The rim of the first bowl has a series of hatched elements typical of the type. A very similar vessel is illustrated by Suhm and Jelks (1962:Plate 71a) from the late 17th to early 18th century Clements sitc (4lCS25) in Cass County. The vessel is lightly polished and appears to have grog temper. On the second Simms Engraved bowl, the decoration is confined to the narrow rim and consists of bands bounded by ticked horizontal lines with hatched elements between bands. Vessels illustrated by Suhm and Jelks (1962:Plate 71f) and Perttula et al. (2010:Figures 20c and 21a) from the Clements site are almost identical to the Powell collection vessel. Its surfaces arc polished but pitted and it is possible that the bowl has shell temper.

The last vessel in the collection is a Maydelle Incised jar (Figure 1f). This medium-sized jar has opposed sets of diagonal incised lines on the everted rim, with a row of punctations at the juncture of the rim and body. Surfaces are rough, as would be expected with a utility ware vessel probably used for cooking over a fire, and the vessel appears to have been made with a combination of bone and grog temper.

\section{STONE ARTIFACTS}

There is a grooved axe in the collection (Figure $1 \mathrm{~g}$ ). It is made from a dark gray porphyritic igneous stone, a raw material that is definitely not local to East Texas; it may have originated in the Ouachita 

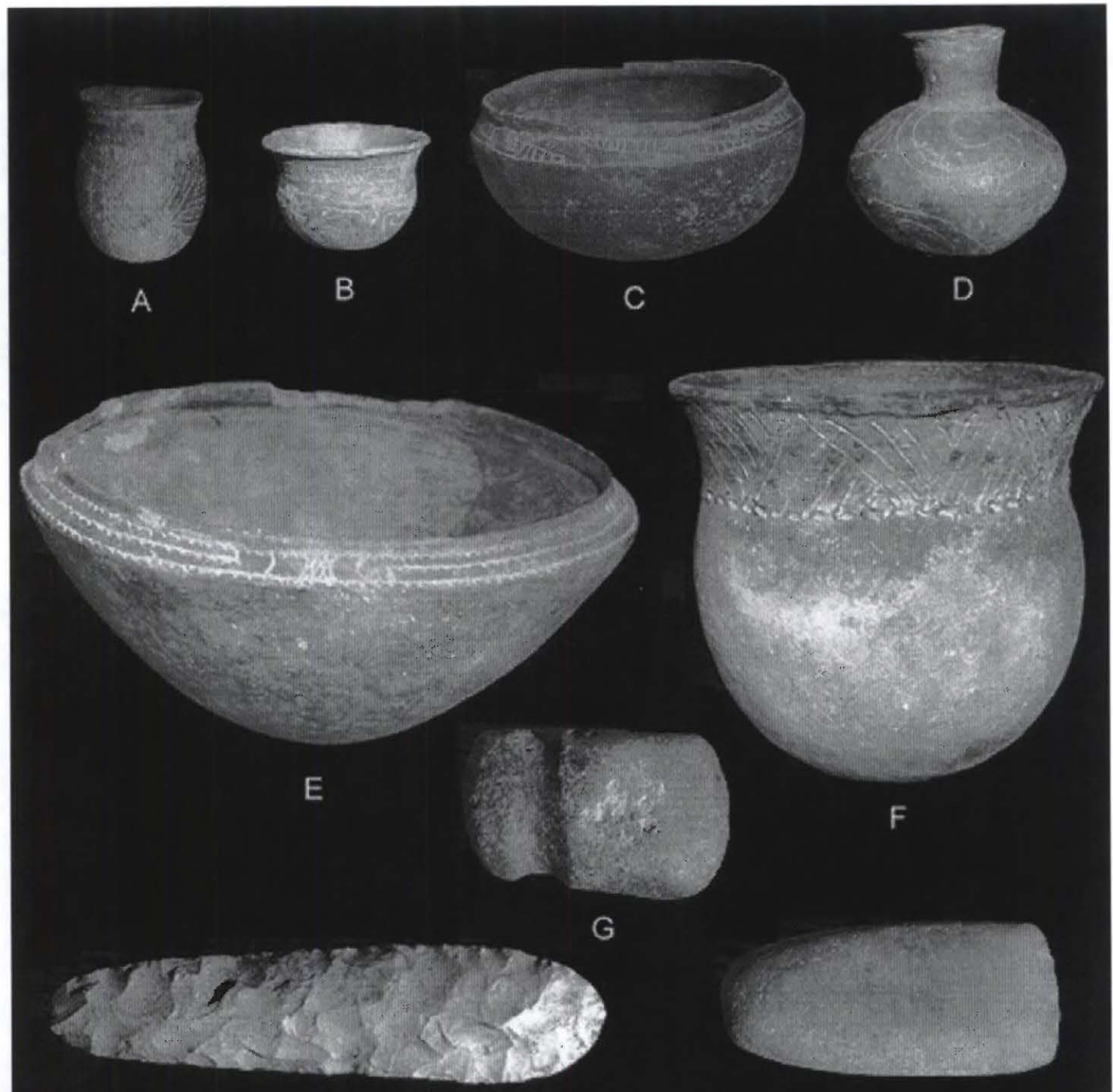

H

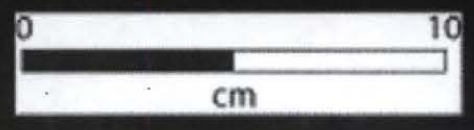

Figure 1. Artifacts in the Raymond Powell Collection: a, possible Pease Brushed-Incised jar; b, d, Taylor Engraved; c, e, Simms Engraved; f, Maydelle Incised; g, grooved axe; h, lenticular biface or chisel; i, celt.

Mountains of southeastern Oklahoma and southwestern Arkansas. One surface is heavily battered on a single surface.

The second stone artifact is a chipped lenticular biface (Figure $1 \mathrm{~h}$ ). This is a large biface of a light gray, non-local chert that contains small brown to tan mottles. The material appears to be Mill Creek chert from southern Illinois (Harry J. Shafer, personal communication 2010; Charles Cobb, personal communication 2010; Ray 2007:247-250). One end is highly polished and has small secondary retouch scars. Cobb (personal communication 2010) classifies this specimen as a "chisel" based on its form. Mill Creek chert 
bifaces were widely distributed among Mississippian groups (Cobb 1989), but have not been reported previously from the Caddo Area.

Finally, there is a celt in the Powell collection (see Figure li). This is a petaloid celt made from a tan fine-grained quartzite or chert. It is pecked on the blunt, flat, proximal end, and the wide hit has chipping scars. Although the material for celt manufacture is unusual, the form is common for celts in the Caddo

Area. One of the celts at the Clements site has the same form (Perttula et al. 2010:Figure 30a, c), although it was manufactured from a green siliceous shale or greenstone, also found in the Ouachita Mountains.

\section{REFERENCES CITED}

Cobb, C. R.

1989 An Appraisal of the Role of Mill Creek Chert Hocs in Mississippian Exchange Systems. Southeastern Archaeology 8(2):79-92.

Perttula, T. K.

1995 The Archeology of the Pineywonds and Post Oak Savanna of Northeast Texas. Bulletin of the Texas Archeological Society 66:331-359.

2004 The Prehistoric and Caddoan Archeology of the Northeast Texas Pineywoods. In The Prehistory of Texas, edited by T. K. Perttula, pp. 370-407. Texas A\&M University Press, College Station.

2005 1938-1939 WPA excavations at the Hatchel Site (41BW3) on the Red River in Bowie County, Texas. Southeastern Archaeology 24(2):180-198.

Perttula, T. K., B. Nelson, R. L. Cast, and B. Gonzalez

2010 The Clements Site (4ICS25): A Late 17th to Early 18th-Century Nasoni Caddo Settlement and Cemetery. Anthropological Papers No. 92. American Museum of Natural History, New York.

Ray, J. H.

2007 Ozarks Chipped-Stone Resources: A Guide to the Identification. Distribution. and Prehistoric. Use of Cherts and Other Siliceous Raw Materials. Special Publication No. 8. Missouri ArchaeoIngical Society, Springfield.

Suhm, D. A. and E. B. Jelks (editors)

1962 Handbook of Texas Archeology: Type Descriptions. Special Publication No. I, Texas Archeological Society and Bulletin No. 4, The Texas Memorial Museum, Austin.

Thurmond, J, P.

1990 Archeology of the Cypress Creek Drainage Basin, Northeastern Texas and Northwestern Louisiana. Studies in Archeology 5. Texas Archeological Research Laboratory, The University of Texas at Austin. 